\title{
Ensefalopati Hepatik pada Sirosis Hati: Faktor Presipitasi dan Luaran Perawatan di RSUD dr. Saiful Anwar Malang
}

\author{
Hepatic Encephalopathy in Liver Cirrhosis: Precipitating Factors and Outcomes at dr. Saiful \\ Anwar Hospital Malang
}

\author{
Suyoso, Syifa Mustika, Harijono Achmad \\ Laboratorium IImu Penyakit Dalam Rumah Sakit Umum Daerah Dr. Saiful Anwar Malang
}

\begin{abstract}
ABSTRAK
Ensefalopati hepatik (EH) menyebabkan kematian pada 30\% pasien sirosis hati. Pengenalan secara dini berbagai faktor presipitasi EH dan pengelolaan yang tepat dapat mencegah angka kematian yang tinggi. Penelitian ini untuk mengetahui faktor-faktor presipitasi EH dan luaran perawatan pada sirosis hati dengan EH, secara cross sectional, dari Rekam Medis pasien EH mulai Januari-Desember 2013 di RSU. Dr. Saiful Anwar Malang. Subjek penelitian adalah 36 pasien sirosis hati, 28 laki-laki dan 8 perempuan, rata-rata berumur 55,3 $\pm 11,69$, dengan EH derajat II 1 pasien (3\%), III 12 (33\%) dan IV 23 (64\%), dengan etiologi terbanyak adalah hepatitis B $15(41,7 \%)$. Faktor presipitasi tersering secara berurutan adalah perdarahan saluran cerna atas 22 pasien (61,1\%), infeksi 18(50\%), dehidrasi $16(44,4 \%)$ hiponatremia 15 (41,7\%), hipokalemia $10(27,8 \%)$ dan konstipasi $7(19,4 \%)$. Sebanyak $28(78 \%)$ pasien mempunyai dua atau lebih faktor presipitasi. Sebanyak 9 pasien (25\%) mengalami perbaikan dan 27 pasien (75\%) meninggal dunia. Secara statistik dengan uji chisquare tidak didapatkan hubungan antara faktor presiptasi perdarahan saluran cerna dengan luaran $(p=0,23)$, dan tidak didapatkan hubungan antara jumlah faktor presipitasi dengan luaran kematian $(p=0,38)$. Nilai rasio prevalens antara satu faktor presipitasi dengan dua faktor presipitasi terhadap kematian =0,429; IK 95\%; 0,2-10, antara satu dengan tiga faktor $=0,1$; KI 95\%; 0,1-17,1,antara satu dengan empat faktor =0,5; KI 95\%; 01-22,6. Penelitian ini menunjukkan faktor presipitasi EH tersering adalah perdarahan saluran cerna bagian atas. Luaran kematian yang tinggi disebabkan multi faktor presipitasi.
\end{abstract}

Kata Kunci: Ensefalopati hepatik, faktor presipitasi, sirosis hati

\begin{abstract}
Hepatic encephalopathy (HE) causes mortality on $30 \%$ of patients with liver cirrhosis. Early recognition on precipitating factors of HE and well treatment can prevent high mortality rate. This cross sectional study aims to determine the precipitating factors and the outcome in liver cirrhosis from EH patients' medical records over a period of January to December 2013. The subjects of this research were 36 patients of liver cirrhosis, 28 males and 8 females, average age was 55,3+11,69 years. 1 patient (3\%) had grade II, while 12 patients (33\%) and 23 patients (64\%) had grade III and IV respectively with Hepatitis $B$ was the main causes of liver cirrhosis as in 15 patients $(41,7 \%)$. In a sequence, the common precipitations of HE to the least were gastrointestinal bleeding in 22 patients (61,1\%), infections in 18 patients (50\%), dehydration in 16 patients (44,4\%), hyponatremia in 15 patients (41,7\%), hypokalemia in 10 patients (27,8\%) and constipation in 7 patients (19,4\%). There were 28 patients (78\%) who had two or more precipitating factors. A total of 9 patients (25\%) had improved and 27 patients (75\%) died. Statistically chi-square analysis showed no correlation between gastrointestinal bleeding and outcome $(p=0,23)$ and no correlation between cumulative precipitating factors and mortality $(p=0,38)$. The prevalence ratio between 1 precipitation factor with 2 precipitation factors towards death was 0,429; IK 95\%; 0,2-10, between 1 precipitation factor with 3 factors was 0,1; IK 95\%, 0,1-17,1, between 1 precipitation factor with 4 factors was 0,5; KI 95\%, 01-22,6. This study shows that the most common precipitating factor of HE is gastrointestinal bleeding. The high mortality rate of hospital outcome is caused by multi precipitating factors.
\end{abstract}

Keywords: Hepatic encephalopathy, liver cirrhosis, precipitating factors

Jurnal Kedokteran Brawijaya, Vol. 28, No. 4, Agustus 2015; Korespondensi: Suyoso. Laboratorium Ilmu Penyakit Dalam Rumah Sakit Umum Daerah Dr. Saiful Anwar Malang, Jl. Jaksa Agung Suprapto No. 2 Malang Tel. (0341)366242 Email:yos_dr@yahoo.co.id 


\section{PENDAHULUAN}

Ensefalopati hepatik (EH) merupakan komplikasi serius dari penyakit hati kronis dan secara luas didefinisikan sebagai perubahan status mental dan fungsi kognitif yang terjadi pada kondisi gagal hati. Ensefalopati hepatik jauh lebih sering terlihat pada pasien dengan penyakit hati kronis (1,2). Manifestasi klinis dari enseflopati hepatik mulai dari yang ringan sampai dengan koma $(2,3,5)$. Sirosis adalah manifestasi stadium akhir dari setiap penyakit hati kronis yang progresif yang ditandai dengan hilangnya parenkim hati, pembentukan septa fibrous dan struktur nodul yang tidak normal (1).

Lebih dari sepertiga pasien sirosis menjalani rawat inap karena ensefalopati hepatik (4). Prevalensi terjadinya ensefalopati hepatik adalah sebesar $30-40 \%$ dari pasien sirosis hati sedangkan untuk ensefalopati hepatik minimal sebanyak $20-80 \%$ (5). Sebanyak $30 \%$ pasien ensefalopati hepatik mengalami kematian (13). Angka prevalensi ensefalopati hepatik yang berobat di RS Dr. Cipto Mangunkusumo Jakarta tahun 1999 dilaporkan 14,9\% (9), sedangkan di Rumah Sakit Umum Daerah (RSUD) Dr. Soetomo Surabaya sebanyak $14,7 \%$ pada tahun $1997-$ 1998 dengan angka kematian 44,7\% (10).

Ensefalopati hepatik secara klinis, berdasarkan kriteria West Haven, ditandai dengan perubahan dalam kesadaran dan perilaku mulai dari perubahan pola bangun tidur dan pelupa (tahap1), kebingungan, perilaku aneh, dan disorientasi (tahap 2), letargi dan disorientasi yang mendalam (tahap 3); koma (tahap 4) (2-4,6). Pada pemeriksaan fisik, tahap awal mungkin menunjukkan hanya tremor distal, namun ciri khas ensefalopati hepatik adalah adanya asterixis $(3,4)$.

Faktor-faktor presipitasi yang sering terjadi pada ensefalopati hepatik dibagi menjadi tiga (1) episodic seperti infeksi, perdarahan saluan cerna atas, penggunaan berlebihan diuretik, kelainan elektrolit, konstipasi dan tidak diketahu, (2) recurrent yaitu jika kejadian EH berulang kurang dari 6 bulan, seperti keainan elektrolit, infeksi, tidak teridentifikasi, konstipasi, penggunaan diuretik dan perdarahan saluran cerna (3) persistent jika perubahan perilaku selalu didapatkan (5). Faktor presipitasi lain seperti dehidrasi, diet tinggi protein dan pengaruh obat yang mempengaruhi sistem saraf pusat serta penyakit lain seperti hepatocelular carcinoma (4). Presipitasi lainnya termasuk konstipasi, alkalosis, dan kekurangan kalium yang disebabkan oleh diuretik, opioid, hipnotik dan sedatif: obat yang mengandung amonium atau senyawa amino, paracentasis dengan hipovolemia yang menyertai, dan shunt porto systemic (termasuk transjugular intrahepatic portosystemic shunt) (2). Berdasarkan faktor presipitasi, esefalopati hepatik dapat dibagi berdasarkan adanya dan tidak adanya faktor presipitasi (5).

Ensefalopati hepatik dianggap merupakan pengaruhbersama daribeberapa faktor seperti amonia, inflamasi dan kelainan elektrolit (7). Amonia telah dianggap sebagaifaktor yang paling penting menyebabkan terjadinya ensefalopati hepatik. Amonia mencapai sirkulasi sistemik melalui shunting porto sistemik dan kegagalan hati untuk metabolisme amonia (7). Kadar yang ekstrim dari amonia telah dapat dilihat pada ganglia basalis dan serebelum pasien sirosis dengan ensefalopati hepatik. Hal ini diyakini memberikan kontribusi terhadap terjadinya peningkatan disfungsi motor dan gejala seperti ekstrapiramidal yang diakibatkan karena perubahan fungsi dan morfologi dari astrosit karena peningkatan kadar amonia (8). Penelitian ini dilakukan untuk mengamati faktor presipitasi yang dapat dikenali dengan cepat, sehingga segera mendapatkan pengelolaan yang tepat untuk mencegah angka kematian yang tinggi pada ensefalopati hepatik.

\section{METODE}

Jenis penelitian ini bersifat observasional cross sectional. Data diambil melalui Rekam Medis pasien Sirosis Hati yang masuk rumah sakit dengan ensefalopati hepatikum periode Januari sampai Desember 2013 di RSUD Dr. Saiful Anwar Malang yang memenuhi kriteria inklusi. Kriteria inklusi yang digunakan yaitu pasien sirosis hati dengan tanda dan gejala ensefalopati hepatik, sedangkan pasien dengan gagal hati fulminant, koma hipoglikemik atau hiperglikemik, stroke dan koma uremikum tidak disertakan dalam penelitian.

Kriteria ensefalopati hepatik menggunakan West Haven. Derajat 1 jika terdapat gangguan kognitif dan perilaku berupa gangguan tidur, penurunan konsentrasi, depresi, ansietas dan gejala neuromuskular berupa suara monoton, tremor, penurunan kemampuan menulis, apraxia. Derajat 2 jika terdapat gangguan kognitif dan perilaku berupa letargi, disorientasi, penurunan daya ingat dan gejala neuromuskular berupa disatria, asteriksis. Derajat 3 jika terdapat gangguan kognitif dan perilaku berupa somnolen, kebingungan, amnesia dan gejalal neuromuskular berupa nistagmus, kekakuan otot, hiper atau hiporeflek. Derajat 4 jika terdapat gangguan kognitif dan perilaku berupa koma dan gejala neuromuskular berupa pupil dilatasi, ditemukan refleks patologis.

Kriteria child classification menggunakan Modified Child Pugh Scoring System disebut klasifikasi A jika total skor 5-6, klasifikasi B jika total skor 7-9 dan klasifikasi C jika total skor 10-15

Skor dihitung dari 5 item. Asites yaitu skor 1 jika tidak ada asites, skor 2 asites ringan, skor 3 asites berat. Ensefalopati hepatik yaitu skor 1 jika tidak ada, skor 2 jika derajat I atau II, skor 3 jika derajat III dan IV. Nilai Bilirubin yaitu skor 1 jika $<2 \mathrm{mg} / \mathrm{dl}$, skor 2 jika 2-3 mg/dl, skor 3 jika > $3 \mathrm{mg} / \mathrm{dl}$. Nilai Albumin yaitu skor 1 jika > 3,5 g/dl, skor 2 jika 2,8-3,5 g/dl, skor 3 jika $<2,8 \mathrm{~g} / \mathrm{dl}$. Prothrombin Time yaitu skor $1 \mathrm{jika}<4$ detik, skor 2 jika 4-6 detik, skor 3 jika > 6 detik dari kontrol

Kriteria faktor presipitasi terdiri dari empat hal sebagai berikut, faktor pertama berupa perdarahan saluran cerna ditandai dengan muntah dan berak berwarna hitam, lalu konstipasi ditandai adanya perubahan pola dan jenis defekasi, berikutnya infeksi ditandai dengan minimal 2 tanda Systemic Inflammatory Response Syndrome (SIRS) berupa suhu tubuh $>38^{\circ} \mathrm{C}$ atau $<36^{\circ} \mathrm{C}$, nadi $>90 x / m$, respiratory rate $>20 \mathrm{x} / \mathrm{m}$, leukosit $>12.000 / \mu \mathrm{L}$ atau $<4.000 / \mu \mathrm{L}$ dengan sumber infeksi dari saluran pernafasan, saluran kencing atau dari saluran cerna, dan yang terakhir hiponatrium jika kadar natrium $<130 \mathrm{mmol} / \mathrm{L}$ serta hipokalemia jika kadar kalium $<3,5 \mathrm{mmol} / \mathrm{L}$.

\section{HASIL}

Selama kurun waktu setahun mulai bulan Januari 2013 sampai Desember 2013 terdapat 36 pasien yang rawat inap dengan sirosis hati yang mengalami ensefalopati hepatikum. Sebagian besar pasien adalah laki-laki dengan 
usia kurang 60 tahun, derajat ensefalopati berat, penyebab terbanyak hepatitis $\mathrm{B}$, child classification $\mathrm{C}$, dan meninggal.

Tabel 1. Karakteristik subjek

\begin{tabular}{lrr}
\hline \multicolumn{1}{c}{ Karakteristik } & Jumlah & $\%$ \\
\hline Jenis kelamin & 28 & 77,8 \\
$\quad$ Laki-laki & 8 & 22,2 \\
$\quad$ Perempuan & & \\
Umur & 24 & 66,7 \\
$<60$ & 12 & 33,3 \\
$\geq 60$ & & \\
Derajat ensefalopati hepatik & 0 & 0 \\
1 & 1 & 2,8 \\
2 & 12 & 33,3 \\
3 & 23 & 63,9 \\
4 & & \\
Penyebab Sirosis Hati & 15 & 41,7 \\
Hepatitis B & 1 & 2,8 \\
Hepatitis B dan C & 8 & 22,2 \\
Hepatitis C & 12 & 33,3 \\
Bukan Hepatitis & & \\
Child Classification & 0 & 0 \\
A & 5 & 13,9 \\
B & 31 & 86,1 \\
C & & \\
Luaran & 9 & 25,0 \\
Hidup & 27 & 750 \\
Mati
\end{tabular}

Keterangan: Child classification adalah klasifikasi prognosis berdasarkan penilaian terhadap ascites, derajat ensefalpati, bilirubin, albumin dan prothrombine time

\section{Hubungan Faktor Presipitasi dan Luaran Pasien}

Pada Tabel 2 diketahui bahwa pada faktor presipitasi perdarahan saluran cerna, pasien yang meninggal sebagian besar adalah pasein yang memiliki faktor ini yaitu sebanyak $50,0 \%$ (18) pasien sedangkan pasien yang hidup sebagian besar adalah pasien yang tidak memilikinya yaitu sebanyak $13,9 \%$ (5) pasien. Terdapat $19,4 \%$ (7) pasien yang meninggal mengalami konstipasi. Pasien dengan hiponatremia dengan kadar $\mathrm{Na}<130$ $\mathrm{mmol} / \mathrm{L}$ sebagian besar meninggal sebanyak $36,1 \%$ (13) pasien, sedangkan pasien yang memiiki kadar $\mathrm{Na} \geq 130$ sebagian besar juga meninggal yaitu sebanyak 38,9\% (14) pasien. Pada faktor infeksi, sebagian besar pasien yang meninggal adalah pasien yang memiliki infeksi yaitu sebesar $41,7 \%$ (15) pasien, sedangkan pasien yang hidup sebagian besar adalah pasien yang tidak memiliki infeksi yaitu sebanyak $16,7 \%$ (6) pasien. Pada faktor hipokalemia, pasien yang mengalami hipokalemia dengan kadar kalium $<3,5 \mathrm{mmol} / \mathrm{L}$ sebagian besar meninggal yaitu sebanyak $22,2 \%$ (8) pasien dan pasien yang mengalami dehidrasi sebagian besar meninggal yaitu sebanyak $36,1 \%$ (13) pasien. Pada faktor perdarahan saluaran cerna atas pasien diketahui bahwa nlai $p$-value sebesar 0,236 nilai tersebut lebih dari 0,05 (alpha) sehingga disimpulkan bahwa tidak terdapat hubungan yang signifikan antara faktor perdarahan saluran cerna dengan luaran perawatan pasien. Begitu pula pada faktor konstipasi pasien diketahui bahwa nlai p-value sebesar 0,808, kemudian faktor hiponatremia didapatkan nilai $p$-value sebesar 0,172 , pada faktor infeksi diketahui nlai $p$-value sebesar 0,248 , pada faktor hipokalemia diketahui bahwa nilai $p$ - value sebesar 0,667 , pada faktor dehidrasi diketahui bahwa nilai $p$-value sebesar 0,432 , sehingga dapat disimpulkan bahwa tidak terdapat hubungan yang signifikan antara faktor-faktor presipitasi dengan luaran pasien.

Pada analisa jumlah faktor presipitasi diketahui bahwa nilai $p$-value sebesar 0,381, maka dapat dikatakan tidak terdapat hubungan yang signifikan antara jumlah faktor presipitasi dengan luaran perawatan pasien.

Tabel 2. Hubungan faktor presipitasi dengan luaran pasien

\begin{tabular}{|c|c|c|c|c|c|}
\hline \multirow{2}{*}{ Faktor } & Hidup & Mati & Total & \multirow{2}{*}{$\chi^{2}$} & \multirow{2}{*}{$\begin{array}{c}P \text { - } \\
\text { value }\end{array}$} \\
\hline & No(\%) & No(\%) & No(\%) & & \\
\hline \multicolumn{6}{|l|}{$\begin{array}{l}\text { Perdarahan } \\
\text { sal cerna }\end{array}$} \\
\hline Tidak & $9(25)$ & $5(13,9)$ & $14(38,9)$ & 1,403 & 0,236 \\
\hline Ya & $18(50)$ & $4(11,1)$ & $22(61,1)$ & & \\
\hline \multicolumn{6}{|l|}{ Konstipasi } \\
\hline Tidak & $22(61,1)$ & $7(19,4)$ & $29(80,6)$ & 0,059 & 0,808 \\
\hline $\mathrm{Ya}$ & $2(5,6)$ & $5(13,9)$ & $7(19,4)$ & & \\
\hline \multicolumn{6}{|c|}{ Kadar natrium } \\
\hline$<130$ & $13(36,1)$ & $2(5,6)$ & $15(41,7)$ & 1,867 & 0,172 \\
\hline$\geq 130$ & $14(38,9)$ & $7(19,4)$ & $21(58,3)$ & & \\
\hline \multicolumn{6}{|l|}{ Infeksi } \\
\hline Tidak & $12(33,3)$ & $6(16,7)$ & $18(50,0)$ & 1,333 & 0,248 \\
\hline \multicolumn{4}{|c|}{ Kadar kalium } & & \\
\hline$<3,5$ & $8(22,2)$ & $2(5,6)$ & $10(27,8)$ & 0,185 & 0,667 \\
\hline$\geq 3,5$ & $19(52,8)$ & $7(19,4)$ & $26(72,2)$ & & \\
\hline \multicolumn{6}{|l|}{ Dehidrasi } \\
\hline Tidak & $14(38,9)$ & $6(16,7)$ & $20(55,6)$ & 0,600 & 0,439 \\
\hline Ya & $13(36,1)$ & $3(8,3)$ & $16(44,4)$ & & \\
\hline
\end{tabular}

Pada penelitian ini dibandingkan risiko kematian pada pasien dengan jumlah faktor presipitasi 2,3,4, dan 5 . Untuk membandingkan risiko kematian pada pasien dengan berbagai jumlah faktor risiko yang dimiliki dapat digunakan analisis Chi Square perkelompok pasien dengan faktor risiko yang berbeda-beda. Hasil menunjukkan tidak terdapat perbedaan risiko kematian yang signifikan antara pasien yang memiliki beberapa jumlah faktor presipitasi terhadap jumlah faktor presipitasi lainnya.

Tabel 3. Hubungan jumlah faktor presipitasi yang dimiliki dengan luaran perawatan

\begin{tabular}{|c|c|c|c|c|c|c|}
\hline $\begin{array}{l}\text { Faktor } \\
\text { Presipitasi }\end{array}$ & $\begin{array}{c}\text { Mati } \\
\text { N (\%) }\end{array}$ & $\begin{array}{l}\text { Hidup } \\
\mathrm{N}(\%)\end{array}$ & $\frac{\text { Total }}{\text { N (\%) }}$ & $\begin{array}{c}\text { Rasio } \\
\text { Prevalensi }\end{array}$ & $\chi^{2}$ & $\begin{array}{c}P \text { - } \\
\text { value }\end{array}$ \\
\hline 2 faktor Vs & $8(36,4)$ & $3(13,6)$ & $11(50,0)$ & \multirow{2}{*}{$0,233(95)$} & \multirow{2}{*}{1,226} & \multirow{2}{*}{0,269} \\
\hline 3 faktor & $10(45,5)$ & $1(4,5)$ & $11(50,0)$ & & & \\
\hline 2 faktor Vs & $8(57,1)$ & $3(21,4)$ & $11(78,6)$ & \multirow{2}{*}{1,165 (95) } & \multirow{2}{*}{0,042} & \multirow{2}{*}{0,837} \\
\hline 4 faktor & $2(14,3)$ & $1(7,1)$ & $3(21,4)$ & & & \\
\hline 2 faktor Vs & $8(57,1)$ & $3(21,4)$ & $11(78,6)$ & \multirow{2}{*}{$\infty$} & \multirow{2}{*}{1,041} & \multirow{2}{*}{0,308} \\
\hline 5 faktor & $3(21,4)$ & $0(0)$ & $3(21,4)$ & & & \\
\hline 3 faktor Vs & $10(71,4)$ & $1(7,1)$ & $11(78,6)$ & & \multirow{2}{*}{1,131} & \multirow{2}{*}{0,287} \\
\hline 4 faktor & $2(14,3)$ & $1(7,1)$ & $3(21,4)$ & & & \\
\hline 3 faktor Vs & $10(71,4)$ & $1(7,1)$ & $11(78,6)$ & & \multirow{2}{*}{0,294} & \multirow{2}{*}{0,588} \\
\hline 5 faktor & $3(21,4)$ & $0(0)$ & $3(21,4)$ & & & \\
\hline 4 faktor Vs & $2(33,3)$ & $1(16,7)$ & $3(50,0)$ & & \multirow{2}{*}{1,200} & \multirow{2}{*}{0,273} \\
\hline 5 faktor & $3(500)$ & $0(0)$ & $3(500)$ & & & \\
\hline
\end{tabular}


Pada penghitungan rasio prevalens antara kelompok dengan satu faktor dengan dua faktor presipitasi didapatkan nilai $=0,429$ dengan interval kepercayaan $95 \%$ 0,16 sampai 10,09 , yang menunjukkan risiko pasien yang memiliki satu faktor presipitasi untuk meninggal adalah 0,429 kali pasien yang memiliki dua faktor presipitasi, yang berarti risiko pasien yang memiliki satu faktor risiko untuk meninggal lebih kecil daripada pasien yang memiliki dua faktor presipitasi, namun tidak bermakna secara statistik. Rasio prevalens antara kelompok dengan satu faktor dengan tiga faktor presipitasi didapatkan nilai $=0,1$ dengan interval kepercayaan 95\% 0,09 sampai 17,08 dan rasio prevalens antara kelompok dengan satu faktor dengan tiga faktor presipitasi didapatkan nilai $=0,5$ dengan interval kepercayaan 95\% 0,07 sampai 22,59, yang menunjukkan risiko pasien yang memiliki satu faktor resiko untuk meninggal lebih kecil daripada pasien yang memiliki beberapa faktor presipitasi, namun tidak bermakna secara statistik

Pada penghitungan rasio prevalens antara kelompok dua faktor dengan tiga faktor presipitasi didapatkan nilai rasio prevalens=0,233 interval kepercayaan 95\%, 0,109-14,541 yang menunjukkan resiko pasien yang memiliki dua faktor resiko untuk meninggal adalah 0,233 kali pasien yang memiliki tiga faktor resiko, namun tidak didapatkan perbedaan resiko kematian pada keduanya. Penghitungan rasio prevalens antara kelompok dua faktor dengan empat faktor presipitasi menunjukkan nilai rasio prevalens $=1,165$ dengan interval kepercayaan 95\%, 0,207-49,05 dan rasio prevalens antara kelompok dengan dua faktor dengan lima faktor presipitasi didapatkan nilai $=\infty$ namun keduanya menunjukkan tidak bermakna secara statistik. Secara keseluruhan meskipun terdapat peningkatan risiko kematian dengan meningkatnya jumlah presipitasi namun secara statistik tidak signifikan.

Pada penghitungan lamanya rawat inap didapatkan ratarata lama rawat inap untuk pasien yang meninggal dunia adalah $3,81 \pm 3,77$ hari sedangkan rata-rata lama rawat inap pasien yang membaik dari ensefalopati hepatikum adalah $6,56 \pm+3,50$ hari.

\section{DISKUSI}

Penelitian ini difokuskan pada penilaian faktor presipitasi karena penelitian lain telah membuktikan bahwa pengenalan dan pengobatan faktor presipitasi merupakan langkah kunci dalam pengelolaan ensefalopati hepatikum $(1,2)$ dan timbulnya ensefalopati hepatikum pada pasien sirosis hepatik adalah indikasi prognosis yang buruk $(11,14)$. Pada penelitian ini laki-laki mendominasi dengan 28 pasien $(78 \%)$ dan sebagian besar pasien adalah diatas 40 tahun, sebanyak 31 pasien (86\%). Pada penelitian lain juga didominasi oleh laki-laki, dengan kelompok usia sering terkena adalah lebih dari 40 tahun $(13,15,16)$. Hampir semua pasien pada penelitian ini berada dalam stadium III/IV yaitu 35 pasien (97\%) yang menunjukkan prognosa yang buruk terkait kematian $(14,17)$. Penelitian yang berbeda menunjukkan ensefalopati dari kelas I sampai kelas IV dengan frekuensi yang beragam $(13,15)$.

Dalam penelitian ini, perdarahan saluran cerna bagian atas (hematemesis-melena) ditemukan pada 22 pasien (61,1\%), dan infeksi pada 18 pasien (50\%). Dua faktor presipitasi yang sering ditemukan pada penelitian lain (17). Alasan paling sering adanya perdarahan saluran cerna (hematemesis-melena) pada pasien sirosis hati adalah hipertensi portal yang mengakibatkan pecahnya varises esophagus (17). Hasil ini lebih besar dari studi yang dilakukan penelitian lain (19). Adanya darah dalam saluaran cerna akan meningkatakan kadar amonia dan peningkatan absorbsi nitrogen dari saluran cerna. Perdarahan saluran cerna sendiri dapat menyebabkan hipoperfusi ke ginjal dan mengakibatkan kerusakan fungsi ginjal sehingga menurunkan bersihan amonia oleh ginjal. Disisi lain tranfusi darah untuk mengatasi perdarahan juga mengakibatkan hemolisa yang mengakibatkan peningkatan kadar amonia (20).

Infeksi sebagai faktor presipitasi ensefalopati hepatikum ditemukan pada 18 pasien (50\%) karena infeksi paru-paru pada 9 pasien $(25 \%)$, infeksi saluran kencing 6 pasien $(16,7 \%)$, spontaneus bacterial peritonitis 2 pasien (5,6\%) dan septik biliar 1 pasien (2,8\%). Pengaruh infeksi terhadap ensefalopati hepatikum dikarenakan semakin meningkatanya metabolisme katabolik di jaringan yang akan meningkatkan level dari amonia pada darah disamping terganggunya fungsi ginjal (20). Tingginya angka infeksi menunjukkan status nutrisi yang buruk pada pasien sirosis hati, termasuk didalamnya adalah intruksi diet yang rendah protein mengakibatkan pasien jatuh pada malnutrisi yang memudahkan terjadinya infeksi $(17,21)$. Berbagai penelitian yang dilakukan dalam setiap rumah sakit yang berbeda mengungkapkan faktor presipitasi yang sama tetapi dengan frekuensi yang berbeda $(13,15,22)$.

Penelitian kami juga menunjukkan terdapat pasien dengan dehidrasi sebanyak 44,4\% (16 pasien). Hiposodium sebanyak 41,7\% (15) pasien. Hipopotasemia pasien sebanyak 27,8\% (10) pasien, konstipasi pasien sebanyak $19 \%$ (7) pasien. Hiposodium dengan kadar sodium dibawah 130 sering ditemukan pada pasien dengan kegagalan hati dimana dapat menyebabkan edema otak ringan yang merupakan faktor yang penting pada patogenesis ensefalopati hepatikum $(9,17)$. Alasan utama untuk ketidakseimbangan cairan dan elektrolit adalah atas penggunaan terapi diuretik, ataupun karena diare dan muntah (19). Penurunan kadar potasium akan mempermudah pembentukan amonia (20). Penelitian serupa juga mendukung hasil kami $(13,15)$. Konstipasi yang terjadi pada pasien ini kemungkinan disebabkan karena diet yang dibatasi dan karena penggunaan yang tidak semestinya dari laktulosa (15). Konstipasi sendiri dapat menyebabkan peningkatan kadar amonia karena peningkatanpenyerapan amonia pada saluran cerna akibat pemecahan protein dan pemanjangan waktu motilitas dari saluran cerna (20).

Dari 36 pasien, 9 pasien (25\%) membaik dari ensefalopati, sedangkan 27 pasien (75\%) meninggal dunia, sama dengan penelitian lain yang menunjukkan tingkat kematian yang tinggi diatas 30\% (13). Dua per tiga dari pasien yang meninggal memiliki lebih dari 2 faktor presipitasi tetapi pada uji statistik tidak didapatkan hubungan yang signifikan antara banyaknya faktor presipitasi dengan kematian. Penelitian ini sama dengan penelitian yang dilakukan oleh Mumtaz et al terdapat dua pertiga kasus kematian dengan faktor presipitasi $\geq 2$ tetapi tidak didapatkan hubungan yang signifikan secara statistik (23). Sama dengan penelitian yang dilakukan oleh Staruss et al tingkat kematian lebih tinggi dicatat pada ensefalopati hepatik dengan faktor presipitasi yang lebih (18). Hal ini menunjukkan bahwa pasien dengan peningkatan jumlah presipitasi memiliki luaran perawatan yang buruk. Disamping memiliki multi faktor presipitasi, pada 
penelitian kami sebagian besar pasien jatuh pada derajat 3 dan 4 dari ensefalopati hepatikum yang menunjukkan angka prognosis yang buruk sesuai dengan penelitian sebelumnya (11). Pada peghitungan rasio prevalens antara perbandingan berbagai jumlah faktor resiko terhadap kematian juga tidak menunjukkan hubungan yang signifikan meskipun didapatkan terjadi peningkatan

\section{DAFTAR PUSTAKA}

1. Bacon BR. Cirrhosis and Its Complications. In: Longo D and Fauci AS (Eds). Harrisson's GastroenterologyHepatology. New York: McGraw Hill Medical; 2012: pp. 419-343.

2. Lawrence $S$ and Friedman. Liver, Biliary Tract, and Pancreas Disorders. In: Papadakis MA, McPhee SJ, and Rabow MW (Eds). Current Medical Diagnosis \& Treatment 49th edition. New York: McGraw Hill Lange; 2010: pp. 622-623.

3. Gracia G. Cirrhosis and Its Sequele. In: Goldman L and Schaffer Al (Eds). Goldman's Cecil Medicine 24th edition. New York: Elsevier Sauders; 2012: pp. 9991007.

4. Munoz SJ. Hepatic Encephalopathy. Medical Clinics of North America. 2008; 92(4): 795-812.

5. Vilstrup H, Amodio P, Bajaj J, et al. Hepatic Encephalopathy in Chronic Liver Disease: 2014 Practice Guideline by AASL and EASL. Alexandria, Virginia: American Association for the Study of Liver Disease; 2014.

6. Nadeem M, Yousaf MA, Zakaria M, Hussain T, and Ali N. The Value of Clinical Signs in Diagnosis of Cirrhosis. Pakistan Journal of Medical Sciences. 2005; 21(2): 121-124.

7. Chatauret $\mathrm{N}$ and Butterworth RF. Effects of Liver Failure on Inter-Organ Trafficking of Ammonia: Implications for the Treatment of Hepatic Encephalopathy. Journal of Gastroenterology and Hepatology. 2004; 19(7): S219-S223.

8. Ahl B, Weissenborn K, van den Hoff J, et al. Regional Differences in Cerebral Blood Flow and Cerebral Ammonia Metabolism in Patients with Cirrhosis. Hepatology. 2004; 40(1): 73-79.

9. Lesmana LA, Nusi IA, Gani RA, Hasan I, dan Sanitoyoso A. Panduan Praktik Klinik Ensefalopati Hepatik di Indonesia. Jakarta: Perhimpunan Peneliti Hati Indonesia; 2014: hal. 1-18.

10. Nusi IA. Penatalaksanaan Masa Kini Ensefalopati Heaptik. Pendidikan Kedokteran Berkelanjutan XIV Laboratorium-SMF Penyakit Dalam FK Unair RSUD Dr Soetomo. Surabaya, 1999; hal. 45-59.

11. Marchesini G, Bianchi G, Amodio P, et al. Factors Associated with Poor Health Related Quality of Life of Patients with Cirrhosis. Gastroenterology 2001; 120(1): 170-178.

12. Ahmed H, Rehman M, Saeedi MI, and Shah D. Factors Precipitating Hepatic Encephalopathy In Cirrhosis rasio prevalensnya pada semakin banyaknya jumlah faktor presipitasi.

Dapat disimpulkan bahwa pendarahan saluran cerna atas merupakan faktor presipitasi HE terbesar. Kematian pada HE lebih banyak ditemukan pada kasus dengan multi faktor presipitasi.

Liver. Journal of Postgraduate Medical Institue. 2001; 15(1): 91-97.

13. Maqsood S, Saleem A, Iqbal A, and Butt JA. Precipitating Factors of Hepatic Encephalopathy: Experience at Pakistan Institute of Medical Sciences Islamabad. Journal of Ayub Medical College Abbottabad. 2006; 18(4): 57-62.

14. Bustamante J, Rimola A, Ventura PJ, et al. Prognostic Significance of Hepatic Encephalopathy in Patients with Cirrhosis. Journal of Hepatology. 1999; 30(5); 890-895.

15. Zakaria M, Hussain SR, Rehman M, Butt A, and Rana GF. Hepatic Encephalopathy; Precipitating Factors in Patients with Cirrhosis. Professional Medical Journal. 2008; 15(3): 375-379.

16. Masood N, Rahopoto Q, Gouri A, and Munir A. Precipitating Factors of Hepatic Encephalopathy in with Cirrhocis of Liver. Medical Channel. 2010; 16(3): 376-379.

17. Ashoor MA, Wahab EA, Elshafey MM, and Afifi AF. Precipitating Factors and Hospital Outcome of Hepatic Encephalopathy In Cirrhotic Patients at Tertiary Centre in Egypt. Journal of American Science. 2012; 8(9): 344352.

18. Strauss E and da Costa MF. The Importance of Bacterial Infection as Precipitating Factor of Chronic Hepatic Encephalopathy. Hepato-Gastroenterology. 1998; 45(21): 900-904.

19. Hayat AS, Shaikh N, and Memon F. Identification of Precipitating Factors in Hepatic Encephalopathy Patients at Liaquat University Hospital Jamshoro. World Applied Sciences Journal. 2010; 8(6): 661-666.

20. Pratomo B. Ensefalopati Hepatik, Current Management of Cirrhosis Complication. Pertemuan IImiah Tahunan XI. Update in Internal Medicine. Oktober 2011; hal. 105-116.

21. Charlton M. Branched-Chain Amino Acid Enriched Suplements as Therapy of Liver Disease. Journal of Nutrition. 2006; 136(1): 295S-298S.

22. Tariq M, Iqbal S, Khan N, and Basri R. Precipitating Factors of Hepatic Encephalopathy. Rawal Medical Journal. 2009; 34(1): 95-97.

23. Mumtaz K, Ahmed U, Abid S, Baig N, Hamid S, and Jafri, W. Precipitating Factors and the Outcome of Hepatic Encephalopathy in Liver Cirrhosis. Journal of the College of Physicians and Surgeons-Pakistan. 2010; 20(8): 514-518. 